\title{
Iranian Christian Converts in Malaysia
}

\author{
Gholamreza Nuei \\ University of Malaya, nuei@siswa.um.edu.my \\ Faisal Ahmad Shah \\ University of Malaya, faisalas@um.edu.my
}

\begin{abstract}
In a majority of Muslim countries, the number of Muslims converting to other religions is not documented. This study investigates a group of Iranians residing in Malaysia, who have converted to Christianity. This article focuses on this subgroup of ex-Muslims to explore the reason of conversion. The data was collected in Kuala Lumpur, Malaysia. We carried out the study through in-depth interviews with 13 people; also, 45 people answered a (quantitative) questionnaire. The research findings revealed some of the typical religious, social and personal reasons behind the conversion of this group of "ex-Muslims." The contribution of their Islamic knowledge (including, qur'anic and hadīthī) also will be assessed.
\end{abstract}

Keywords: conversion from Islam to Christianity, apostasy, Iran, Malaysia

\section{Introduction}

People who live in pluralistic societies, in general, and Western societies, in particular, freely convert to the religion of their choice without fear of social or legal consequences. By contrast, Muslims who live in Muslim countries face ostracism, ridicule, physical violence and legal persecution leading to severe sentences, including capital punishment. ${ }^{1}$ Islamic law forbids members of the community to change their religion. Nevertheless, many Muslims leave Islam annually. In an interview between Maher Abdallah and Ahmed Katani on Al-Jazeera, the latter said, "six million Muslims leave Islam every year." According to the Townhall Magazine, thousands of Muslims are becoming Christians annually. Shaikh Ahmad al-Katani believes that it is a tragedy in

1 To know more about the types of punishment in Islamic Law, see Shaikh Abdu Rahman, Punishment of Apostasy in Islam (Selangor: The Other Press, 2006), and Mohamed S. El-Awa, Punishment in Islamic Law (IL: American Trust Publication, 1981).

2 "6 Million Muslims LEAVE Islam Every Year," website Virtue Online, www .virtueonline.org/portal/modules/news/print.php?storyid=3995 
the Muslim world. ${ }^{3}$ The reasons and justifications for conversion of Muslims to Christianity changes from country to country. These conversions are the subject of a lot of curiosity and concerns in Muslim and non-Muslim countries. There is much literature on this subject. Social networks are awash with clips of various confessionals of converts. However, there is still dearth of studies addressing this topic.

Many scholars think that politicization of Islam is undoubtedly one cause for these conversions. Also, the debates over freedom of religion are at the centre of these debates. For more than five decades, the freedom has been ensconced in the Universal Declaration of Human Rights. Some Muslim scholars raised objection that Human Rights are used as an instrument of Islamophobia throughout the world."

There are Muslim thinkers who refer to Qur'anic verses to support the right of freedom of religion in Islam. They refer to Q2:256 that states, "Let there be no compulsion in religion." However, Islamic Law and traditional scholarships (i.e. shar', fiqh and sunna) do not allow Muslims to convert. If someone is born into a Muslim family, they must remain a follower of Islam. ${ }^{5}$ Otherwise, they would be punished by death. The references to punishment are mostly based on prophetic traditions, ahădīth, including the following one:

The blood of a Muslim man is not lawful, except for one of three (cases): Illegitimate sexual relations after Ihsan (having

3 Chuck Colson, "They Want Jesus Instead": Why Muslims Convert, The Ginger Jar, website https://gingerjar2.wordpress.com/2008/03/25/they-wantjesus-instead-why-muslims-convert/ (for more information about Muslim conversions in North Africa see: Nadia Marzouki, "Conversion as Statelessness: A Study of Contemporary Algerian Conversions to Evangelical Christianity," Middle East Law and Governance 4 (2012), 69-105.

4 This could be interpreted as a statement clearly in favour of religious freedom and the right to freely renounce Islam and convert to any other religion. See: The Case of an Afghan Apostate- the Right to a Fair Trial Between Islamic Law and Human Rights in Afghan Constitution (Mandana Knust Rassekh Afshar). Other Qur'an verses that promote religious freedom are Q 6:104, Q 3:20, and Q 16:9.

5 For contemporary argument about this law; and criticisms and doubts raised by contemporary Islamic scholars, see: Mohammed Abed al-Jabri, Democracy, Human Rights and Law in Islamic Thought (n.p.: I. B. Tauris \& Co Ltd, 2009), 177. 
been married), or apostasy after Islam, or taking a life without right, for which he is killed.' By Allah! I have never committed illegitimate sexual relations, not during Jahiliyyah nor during Islam, and I have not committed apostasy since I gave my pledge to the Messenger of Allah (s.a.w.), and I have not taken a life that Allah had made unlawful. So for what do you fight me? ${ }^{6}$

United Nations reports that the death penalty for those who have left Islam remains an occurrence in some Muslim communities. $^{7}$

\section{Statement of the Problem}

The number of Muslims converting to Christianity is poorly documented. For obvious reasons, the majority of converts from Islam do not make public announcements of their act. Therefore, statistics available on this issue are notoriously unreliable. This study aims to clarify the reasons behind conversion among a small group of Muslims: Iranian newcomers residing in Malaysia. One of our main objectives is to show how and why people who agree with conversion, experience and justify it. More importantly, the readers will be acquainted with the feelings of potential converts who are unable to actualize their wish.

According to Malcolm L. Rigsby, religious conversion has both sectarian-religious and secular-political dimensions. ${ }^{8}$ Therefore, the self-evaluation and inner understanding of the

6 Muhammad ibn 'Īsā as-Sulamī aḍ-Darīr al-Tirmīdhī, Jāmi' al-Tirmidhī (English Translation), IV, Book 7, no. 2158.

7 In fact, the "Apostasy" issue plays a role on both sides of a coin; one is the Islamic side; and the other one is the contemporary issues and its status in the Human Right Declaration. Hence, many Western and Muslim scholars have discussed the issue. They can be divided into two categories: Adherents who are mostly the jurists and classical interpreters; they assume that the execution is a certain decree for an apostates. Opponents who are mostly living in the contemporary (pre-modern to modern) era; they believe that those who assumed the Qur'anic verses and hadith about apostasy are irrelevant with Human status and rights.

8 Malcolm L. Rigsby, "Religious Conversion in Prison and Its Directions: Community Identity, Religious Dogma, and Exclusivist or Inclusivist Religiosity in American Prisons" (PhD Thesis, Texas Woman's University, 2012). 
participant as well as their communal identity were of interest to our study.

There is no formal report of the number of those Muslims who convert to Christianity. However, reports claim that this number is growing day by day, as the majority of them simply leave Islam wordlessly.

In order to have a clear understanding of how and why they wish to convert to Christianity, pursuing a sound and reliable methodology is required. This survey was to examine the main reasons of this conversion and answer this fundamental question based on the personal experiences of converts.

On the other hand, through analysing the interviews conducted with the converts, we obtained a better understanding of conversion to see whether it is a religious phenomenon or a political one.

\section{Conversion, Christianity and Iran}

The issue of apostasy goes back to the birth of Islam when the first Caliph, Abū Bakr, waged the Wars of Apostasy (hurūb al-ridda) ${ }^{9}$ against the tribes who wanted to leave Islam, thinking their embrace of Islam was a contract between them and Prophet Muhammad. Although that was a particular historical moment, the issue has been enshrined in Islamic law (Shari' $a$ ) as an injunction against any kind of conversion. Leaving Islam still remains one of the biggest social and political taboos in many Muslim countries and is widely considered as a betrayal of God and country. ${ }^{10}$

Although today Islamic states do not often exactly the death penalty, other forms of persecution and ostracism could lead to a sort of "civil death" for most apostates. This could be the reason why some converts emigrate to other countries. ${ }^{11}$ Contemporary Muslim nations often refrain from execution of apostates. Nevertheless, many ex-Muslims converts claim that they face persecution from the government as well as the society and even

9 Fred M. Donner, The Early Islamic Conquests (n.p.: Princeton University Press, 1981).

10 See Johanna Pink, “A Post-qur'ānic Religion Between Apostasy and Public Order: Egyptian Muftis and Courts on the Legal Status of the Bahā'ī Faith", Islamic Law and Society 10, no.3 (2003), 409-434.

11 Iran: Reports of convictions for apostasy in Iran within the last 5 years; Ireland: Refugee Documentation Centre; 12 September 2012 
their family members. ${ }^{12}$ If they do not leave the country, they must remain silent about their decision for fear of social, legal and political repercussions of such a public act.

Since 1956, the contribution that minority religions have made to the population of Iran has always been decreasing. The reasons for this can be the low growth rate of population among the minority religions as well as high rate of immigration among them. Minority religions are mostly populated in urban areas with much less population in countryside. Furthermore, the minority religions, especially the Christians, are distributed all over the country in 31 provinces. ${ }^{13}$ Population ratios of minority religions are shown in Fig. 1. In city of Tehran, as the capital of Iran, $0.26 \%$ of the pollution are Christians. However, their local distribution in Tehran indicates a spatial centralization in choosing their accommodations.

Fig. 1: Population ratios of Zoroastrians, Jewish and Christians from 1956 to 2011

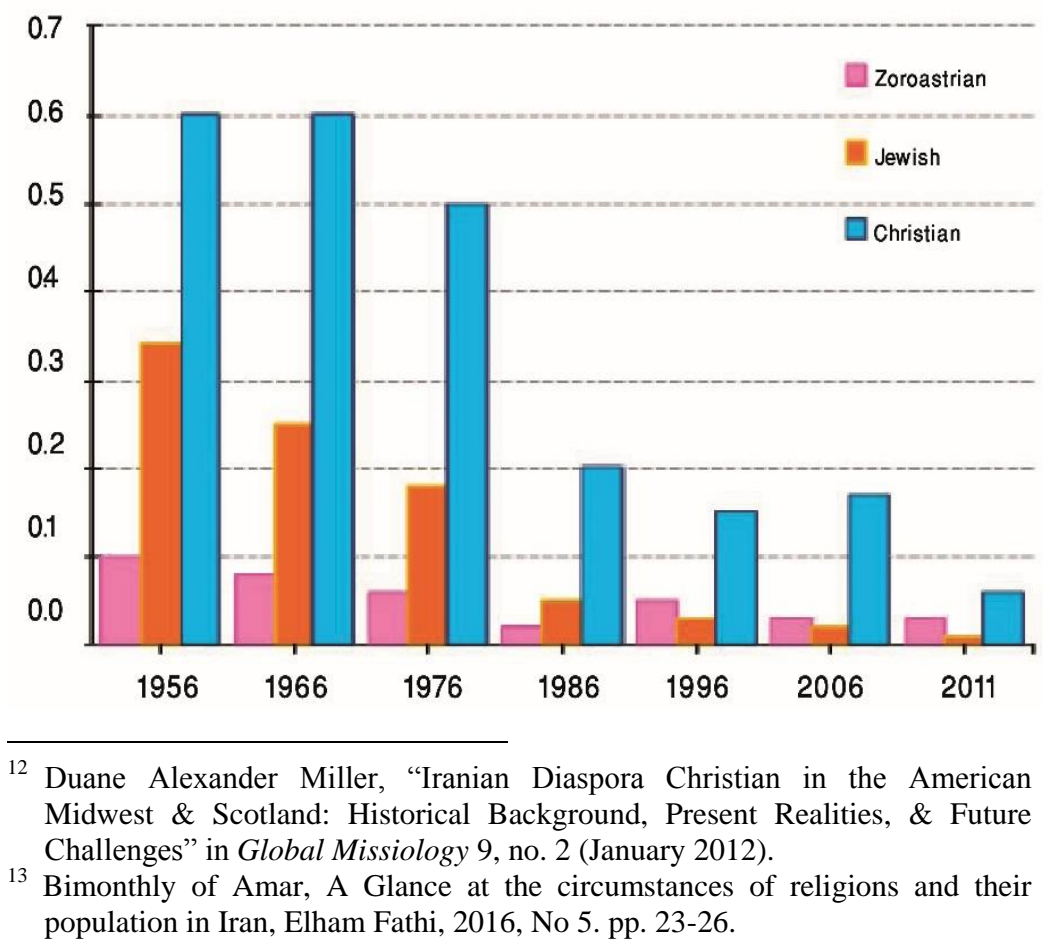


The majority of Iranian Christians are ethnic Armenians and Assyrians who have lived there for millennia. 300,000 Christians live in Iran, the majority of whom are Armenians. The Assyrian Christian population ranges between 10,000 and 20,000. Officially recognized as the "minority" Christians of Iran, they are relatively free to follow their faith. ${ }^{14}$ However, the situation is different for Muslims who convert to Christianity, as they are labelled as apostates.

Iran's Penal Code does not have formal laws against apostasy. ${ }^{15}$ Therefore, the persecution of converts is not based on the promulgated law. However, the Article 167 of the Penal Code gives judges wide latitude when laws do not exist: "In the case of the absence of any such law [the judge] has to deliver his judgment on the basis of authoritative Islamic sources and authentic fatwa." Due to this linkage between Islamic Law and the Iranian courts, the death penalty for an apostate remains a real possibility. Amazingly, the fatwas of grand Mullahs i.e. Āyatullāhs differ on this subject. ${ }^{16}$

An examination of the data reflects that official executions for apostasy are relatively rare in Iran, and that no Christian has ever been officially executed there. On the other hand, there is no specific information about the treatment of those who convert from Islam to Christianity by the courts. ${ }^{17}$

\section{Method, Design, and Data Selection}

Qualitative methods were employed in this study to explore two questions:

14 To read about Christians in Iran, see: Jes Peter Asmussen, "Christians in Iran," The Cambridge History of Iran 3, no.2 (1983), 924-948.

15 The judges often add the charge of muharrib (one who is in war with God) for the execution of the apostates.

16 An increasing number of contemporary Iranian thinkers have called for a reevaluation of the shari'a position on the death penalty for apostasy. For example, the late Ayatollah Hussein Ali Montazeri argued that the death penalty for apostasy was originally prescribed to punish only political conspiracies against the nascent Islamic community; Montazeri believed Muslims today should be free to convert.

17 The Human Rights Campaign mentions cases in which Christians are charged with apostasy: The Cost of Faith Persecution of Christian Protestants and Converts in Iran, p. 8. 
1. Why some Iranian Muslims living in Kuala Lumpur have abandoned Islam?

2. What are the religious, social and personal reasons encouraging Iranian Muslims to convert to Christianity ${ }^{18}$

Converts were invited to narrate their story of conversion in their mother tongue i.e. Persian language. Interviews were conducted during specific hours fixed by the participants in a coffee shop or their houses. However, a majority of them were interviewed after Sunday services. Interviews lasted between 90 minutes and two hours. Each interview was followed by a brief 30-minute follow-up session. Thirteen members of Iranian converts were selected for the study (see Table 1 for the sample size and descriptive).

In addition, for more access to the data, institutional analysis methods and analysis of documents were used. In the grounded theory methodology, 13 Iranians were interviewed and the data was analysed using open, axial and selective coding. The interviews were conducted using a semi-structured interview question guide. While the questions served as a guide, this did not bind the interview to a concrete set of questions. Rather, the questions served as a point of departure as well as rapport and trust developed between each participant and the interviewer (Marshall and Rossman, 2006). They were flexible and allowed the subject to explore and adjust their responses.

18 Patton, and Marshall and Rossman, define qualitative research as uncovering or focusing upon the "individual lived experience." It seeks to interpret a complex social interaction. I chose this method because of its holistic approach to examining phenomena while assuring systematic reflection by the researcher. 
Table 1: 13 Ex-Muslims Agreed to Take Part in the Study (The Sample Size and Descriptive)

\begin{tabular}{|c|c|c|c|c|c|c|c|}
\hline 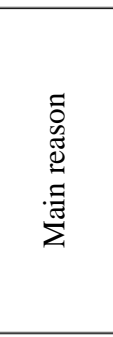 & 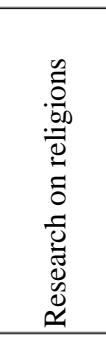 & 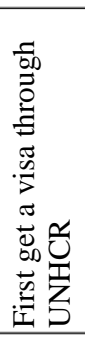 & 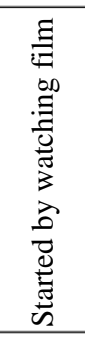 & 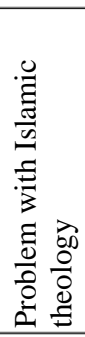 & 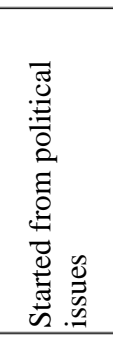 & 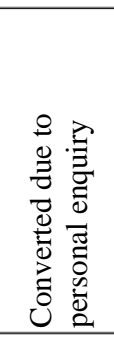 & 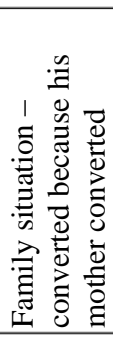 \\
\hline 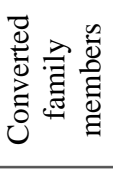 & & 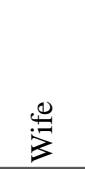 & & 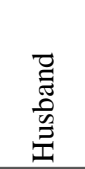 & & & 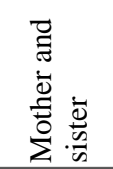 \\
\hline 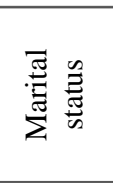 & 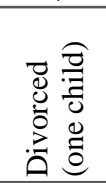 & 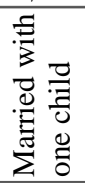 & 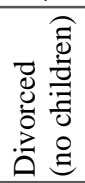 & 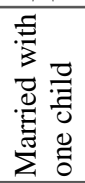 & $\begin{array}{l}\frac{0}{60} \\
\stackrel{=}{n}\end{array}$ & $\begin{array}{l}\frac{0}{60} \\
\stackrel{\Rightarrow}{=}\end{array}$ & $\begin{array}{l}\frac{0}{b D} \\
:\end{array}$ \\
\hline 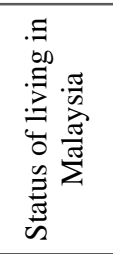 & 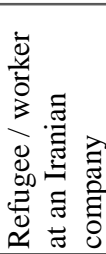 & 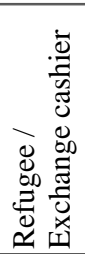 & 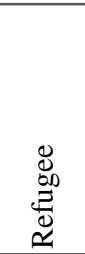 & 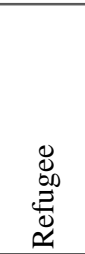 & 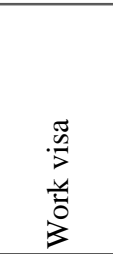 & 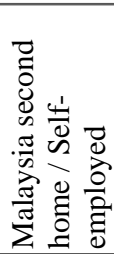 & 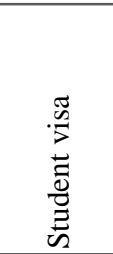 \\
\hline 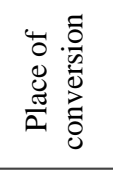 & ฐ్త్ & 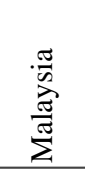 & 蛋 & 芯 & 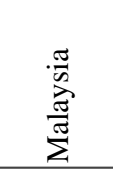 & ञ & $\begin{array}{l}\frac{\pi}{\pi} \\
\frac{\pi}{\pi} \\
\frac{\pi}{\pi} \\
\end{array}$ \\
\hline 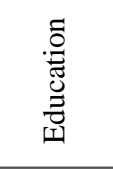 & $\begin{array}{l}\frac{\tilde{\sigma}}{\pi} \\
\frac{\tilde{J}}{\tilde{J}} \\
\ddot{n}\end{array}$ & 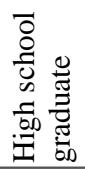 & 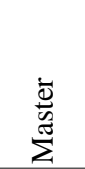 & 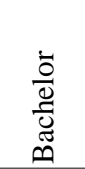 & 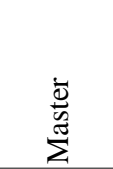 & $\begin{array}{l}\frac{\ddot{0}}{\tilde{D}} \\
\frac{\tilde{U}}{\tilde{U}} \\
\ddot{\emptyset}\end{array}$ & $\begin{array}{l}\overline{8} \\
\overline{0} \\
\overline{0} \\
\overline{0} \\
.00 \\
\overline{1}\end{array}$ \\
\hline Age & if & $\tilde{\omega}$ & ले & p & $\bar{m}$ & $\hat{\lambda}$ & $\beth$ \\
\hline Gender & $\Sigma$ & $\Sigma$ & $\Sigma$ & 工 & $\omega$ & $\Sigma$ & $\Sigma$ \\
\hline 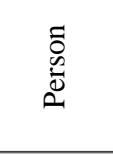 & $\begin{array}{l}-\overrightarrow{2} \\
\dot{2} \\
\dot{z}\end{array}$ & 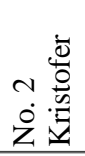 & 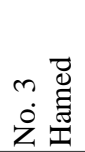 & $\begin{array}{l}+\frac{\pi}{0} \\
\dot{0} \\
\dot{0} \\
z\end{array}$ & 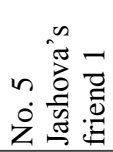 & 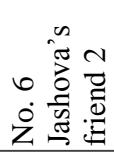 & 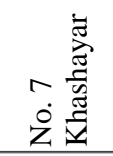 \\
\hline
\end{tabular}




\begin{tabular}{|c|c|c|c|c|c|c|}
\hline 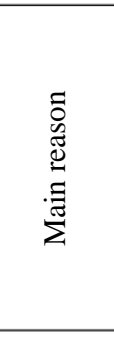 & 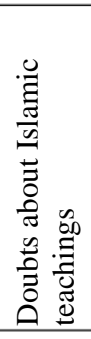 & 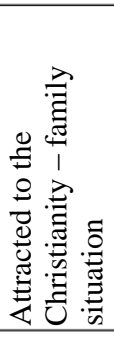 & 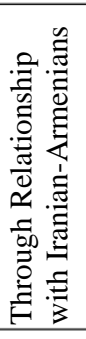 & 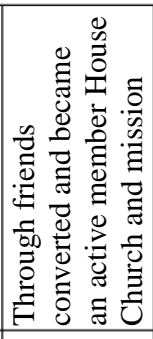 & 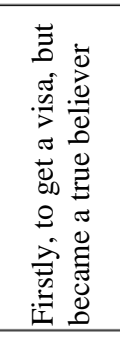 & 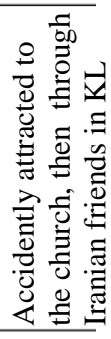 \\
\hline 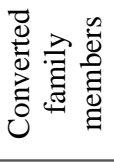 & 1 & 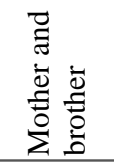 & 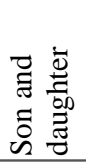 & 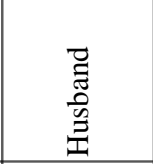 & 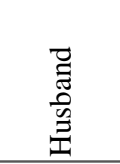 & 1 \\
\hline 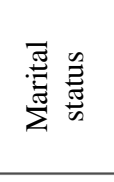 & $\begin{array}{l}\frac{0}{00} \\
\stackrel{=}{0}\end{array}$ & $\begin{array}{l}\frac{0}{00} \\
\stackrel{0}{0}\end{array}$ & 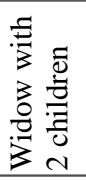 & 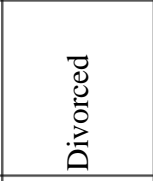 & 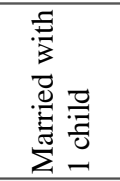 & 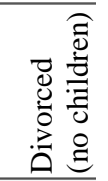 \\
\hline 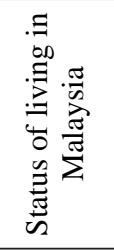 & 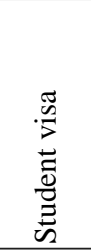 & 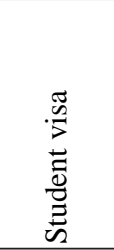 & 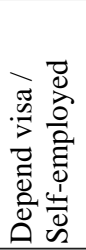 & $\begin{array}{l}\mathscr{D} \\
\stackrel{\infty}{0} \\
\stackrel{2}{0} \\
\widetilde{\simeq}\end{array}$ & 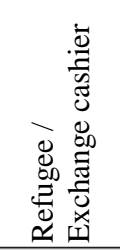 & 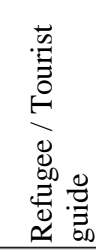 \\
\hline 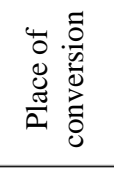 & 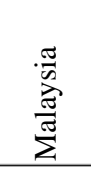 & 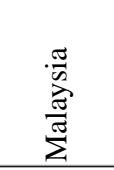 & $\begin{array}{l}\varangle \\
\text { వి }\end{array}$ & 苂 & $\frac{\cdot \frac{\pi}{2}}{\hat{D}^{\frac{\pi}{\pi}}}$ & $\frac{. \frac{\pi}{\omega}}{\sum_{\pi}^{\frac{\pi}{\pi}}}$ \\
\hline 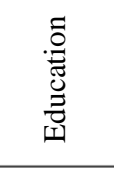 & $\frac{\dot{\bar{d}}}{\stackrel{\Xi}{\Sigma}}$ & 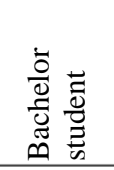 & 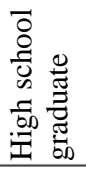 & 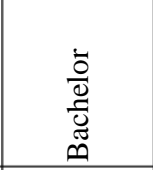 & 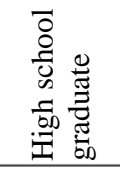 & $\begin{array}{l}\frac{5}{D} \\
\frac{\tilde{D}}{\tilde{I}} \\
\oplus\end{array}$ \\
\hline Age & 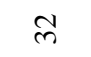 & 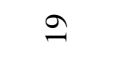 & $\stackrel{\infty}{+}$ & $m$ & શે & $\hat{n}$ \\
\hline Gender & $\Sigma$ & IL & I & I & I工 & $\Sigma$ \\
\hline 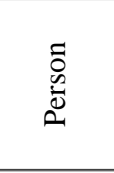 & 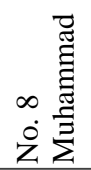 & 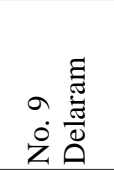 & 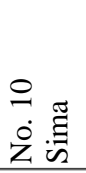 & $\begin{array}{l}\beth \\
\dot{2} \cdot \frac{\pi}{0} \\
\end{array}$ & 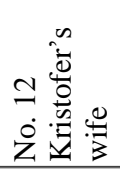 & $\begin{array}{l}\cong \dot{\bar{D}} \\
\dot{0} \\
\dot{z} \\
\bar{z}\end{array}$ \\
\hline
\end{tabular}




\section{Qualitative Coding Procedures}

The population of interest for this study was comprised of Iranians living in Kuala Lumpur who converted to Christianity. As mentioned before, due to the difficulties of finding interviewees from a relatively small research base, the 'snow ball' method ${ }^{19}$ was used to locate suitable individuals. After an interview, a data analysis was performed using a data coding method in the form of open, directional, and optional coding (Table 2). First, the process of obtaining detailed concepts from general concepts and interpreting them was performed through a line-by-line investigation to obtain deeper concepts. Here we used open and directional coding considering the dimensions and size of events not focusing on their frequency. In other words, each line of the interview was described as a concept. These concepts were arrived at by open coding. Then, directional coding was obtained according to different phrases. Eventually, a more general label as a directional code specified them. By putting the obtained concepts together, major concepts emerged. Finally, we arrived at a paradigmatic model, which explained the problem.

\section{Quantitative Survey Sampling the Questionnaire and Scale}

After gaining the sample via the "snow ball" method, a questionnaire was made for the interviews. The questionnaire had two parts: (a) demographic information and (b) substantive information. In this questionnaire, the questions were made according to Likert scale having the choices of "defiantly agreed," "agreed," "neutral," "disagreed", and, "definitely disagreed." SPSS was used to analyse the acquired data. Inferential statistic tests such as regression, correlation, and variance analysis were used to analyse the data.

19 Snowball sampling is a method typically used with unknown or rare populations. Members of these populations have not all been previously identified and are more difficult to locate or contact than known populations. We used the method because the population of so-called apostates in Malaysia could be characterized as 'unknown' as there was no contains contact information list for them. 


\section{Limitations and Strengths}

The nature of investigating the individual belief is sensitive and controversial. It can also be very difficult to locate and gain the trust of a persecuted community. The research has the potential to cause further problems for those who agree to be interviewed even if extreme caution is taken. We, therefore, spent six months finding our subjects.

As apostasy is considered a crime in Iran, it has far-reaching consequences affecting inheritance, marriage, and custody of children. In some cases, it leads to compulsory divorces. Due to these security concerns, the interviewees insisted on remaining anonymous. They were reluctant to reveal where they had been baptized in Iran or Malaysia.

Table 2: Data coding and concepts regarding how and why somebody convert to Christianity

\begin{tabular}{|c|c|}
\hline $\begin{array}{l}\text { The } \\
\text { conversions } \\
\text { problems in } \\
\text { Iran }\end{array}$ & $\begin{array}{l}\text { Family responses: Rejection by family, breaking off all } \\
\text { contact with family, being removed from their homes the } \\
\text { shame of their son leaving Islam, and being ostracized by } \\
\text { their family, brother and sister converted, family's } \\
\text { conversion to Christianity. } \\
\text { Social responses: violence against conversions, loss of } \\
\text { friends and problems arising within social networks, facing } \\
\text { persecution in Iran, not being able to practice their new } \\
\text { religion, being unable to attend church, no services in Farsi, } \\
\text { the churches being not open to all, limited services on } \\
\text { Sundays, the house churches being secret, employment } \\
\text { incompatibility with conversions beliefs, economic problem } \\
\text { for conversions, being too hard to speak to people about this } \\
\text { directly, hiding their change of faith, being persecuted by } \\
\text { radical groups, and extremely dramatic reactions from } \\
\text { Muslims. }\end{array}$ \\
\hline $\begin{array}{l}\text { Benefits and } \\
\text { disadvantages } \\
\text { of Malaysia } \\
\text { for a new } \\
\text { Christian }\end{array}$ & $\begin{array}{l}\text { Living in refugee status in Malaysia, two churches with } \\
\text { Persian-speaking in KL, being harmed if returned to } \\
\text { Iran, attending church regularly, living in fear, being at } \\
\text { risk on returning to hometown, fear of Iranian Security } \\
\text { and Intelligence. }\end{array}$ \\
\hline $\begin{array}{l}\text { Benefits and } \\
\text { tendency } \\
\text { toward } \\
\text { Christianity }\end{array}$ & $\begin{array}{l}\text { The lifestyle of Christians: happiness, peace, being } \\
\text { good to others, easy religion, the Bible being more } \\
\text { clear and making sense, giving service to others, } \\
\text { kindness and love, truthfulness, honesty, Christianity is } \\
\text { more fun, Christianity teaches Christians to love and } \\
\text { forgiving others, being more tolerant than Islam, Most } \\
\text { loving, no gap between the moral profession and the }\end{array}$ \\
\hline
\end{tabular}




\begin{tabular}{|c|c|}
\hline & $\begin{array}{l}\text { practice of Christians, compassion, } \\
\text { Christian propaganda and missionary efforts: websites } \\
\text { closely associated with churches, Christian missionary } \\
\text { efforts, distributing CDs about Bibles and the life of } \\
\text { Christ, Feel comfortable with evangelism, website } \\
\text { belonging to the Farsi Christian News Network, house } \\
\text { churches, through radio and television evangelism, } \\
\text { Relationship with Persian-Armenian, radio and } \\
\text { television evangelism, television evangelism into } \\
\text { Persian, Inviting others to Christ, Inviting friends, } \\
\text { family, and co-workers to church, Encourage others to } \\
\text { follow Jesus Christ, Get social or financial support, } \\
\text { Parties hosted by non-Muslims, social and emotional } \\
\text { and physical support, receive confirmation letter and } \\
\text { acceptance from pastor church. }\end{array}$ \\
\hline $\begin{array}{l}\text { Social-politic } \\
\text { reasons }\end{array}$ & $\begin{array}{l}\text { Affect of the political situation: Religious rule, no } \\
\text { freedom in Islamic Republic regime, the social and } \\
\text { communal intolerance, many instances mistreatment, } \\
\text { fanatic Islamic government, doesn't give women right, } \\
\text { the Refugee Convention, hate Iranian government. }\end{array}$ \\
\hline $\begin{array}{l}\text { Religious } \\
\text { reasons }\end{array}$ & $\begin{array}{l}\text { The level of knowledge and learning about Islam: } \\
\text { Little knowledge of Islam, Weak Iman, a true believer, } \\
\text { Have a religious basis, performing daily prayer, Don't } \\
\text { know how to pray, has Fasted the month of Ramadhan, } \\
\text { wasn't a real Muslim, was a Mu'min believes in } \\
\text { everything God said in the Holy Qur'an, a doubt about } \\
\text { the validity of Islam, confusion, a true believer, a very } \\
\text { strict (religious) parents, an extremely strict Muslim } \\
\text { family, family wasn't too strict, atheist family, Family } \\
\text { Pressure in Religious Matters, have been forced to } \\
\text { study the Qur'an, extremely open mind, Didn't know } \\
\text { how to pray, Family Pressure in Religious Matters. } \\
\text { Doubt about Islam: Associated Islam with extremism, } \\
\text { Islam allowed stoning, must pray, the family wasn't } \\
\text { too strict, forced to study the Qur'an, extremely open } \\
\text { mind, Islam is based on blind love, Haven't Spiritual } \\
\text { Comfort and relaxed and peaceful in Islam, Islam } \\
\text { encourages Muslims to judge another, Religious capital } \\
\text { in Islam, Domestic violence, Islam Women's rights, } \\
\text { The divorce rights of women in Islam The power of } \\
\text { God, Strong faith Forced to wear a hijab, Family } \\
\text { pressure to wear religious dress. } \\
\text { Doubt about Qur'an: it is written by humans, The } \\
\text { Qur'an is creations from the minds of Mohammad, } \\
\text { Didnot know how recitation of Qur'an, understand the } \\
\text { meaning of the Qur'an no one would answer the } \\
\text { questions about doubts with the Qur'an. }\end{array}$ \\
\hline
\end{tabular}




\begin{tabular}{|c|c|}
\hline $\begin{array}{l}\text { Conversions } \\
\text { based on } \\
\text { research }\end{array}$ & $\begin{array}{l}\text { Comparison of religions: Critical Research } \\
\text { Zoroastrianism in Iran, a wide-ranging discussion on } \\
\text { Judaism, a brief research on Buddhism in KL, } \\
\text { Research on Hindu in KL, having studied a Bible, } \\
\text { Studying on the other types of Islam: Sufi, } \\
\text { Ni'matullāhi (a Sufi order or tariqa). }\end{array}$ \\
\hline
\end{tabular}

\section{Analysis of the Results}

The survey questionnaire began with some background information about the participants. Totally, forty-five ex-Muslims were interviewed. The ages of the participants were grouped as in Table 3 . The age had a range of $18-44$, with ages grouped less than $20,21-26,27-32,33-38$, and over 39. The results showed that $37.8 \%$ of the respondents were 27 to 32 .

Table 3: Frequency and percentage distribution of converts' ages

\begin{tabular}{|c|c|c|c|c|c|c|}
\hline Age & 18 & 20 & 21 & 22 & 23 & 24 \\
\hline Frequency & $3(6.7)$ & $2(4.4)$ & $3(6.7)$ & $1(2.2)$ & $3(6.7)$ & $4(8.9)$ \\
\hline Age & 28 & 32 & 33 & 34 & 35 & 36 \\
\hline Frequency & $1(2.2)$ & $4(8.9)$ & $4(8.9)$ & $8(17.8)$ & $2(4.4)$ & $4(8.9)$ \\
\hline Age & 40 & 41 & 42 & 43 & 44 & \\
\hline Frequency & $1(2.2)$ & $1(2.2)$ & $1(2.2)$ & $1(2.2)$ & $1(2.2)$ & \\
\hline
\end{tabular}

The gender and age of the converts are also reported. Twentyone $(46.7 \%)$ participants were male and $24(53.3 \%)$ were female. The percentage of the women was slightly higher than that of the men $6.6 \%$. One of the most obvious results was that the converts were adults between 18 and 32 (64.5\%). This is in agreement with anecdotal evidence suggesting that converts among Iranian populations do not usually convert at higher ages. The results of this study indicated that there was a strong correlation between college graduates and conversion, so that $49.7 \%$ of the converts held a high school diploma or bachelor's degrees. The survey revealed that most participants left their childhood faith before the age 32 and most of them (26 participants) said they had converted to Christianity before reaching the ages $21-26$. Very few changed religions after reaching 39 .

The ages of subjects ranged from 17 to 48 . The gender distribution among the converts was five females and eight males. 
We had four high school graduates, six bachelors and three master's holders. Eight were married and five were single. Five had converted in Iran and seven in Malaysia and one in another country.

Most participants had something to say about their experience in Malaysia. The majority of Iranian converts regularly attended the church. In most narratives, it appeared that they were satisfied with the living conditions in Malaysia; they were able to practice their religion freely and were able socialize and worship openly with other Christians. ${ }^{20}$ In this regard, a male participant said,

"The final destination for me as a refugee is a western country... there's just one problem: We can't make money as a refugee, but it's a peaceful place to live with your new religion. There are churches with English and Persianspeaking members in Kuala Lumpur. Although, I have lost some of my relationships with Muslim community, I have started a new life in Malaysia, with new friends."

One subject, an active proselytizer and a trained Baptist missionary, who is well known among the Iranian convert community of KL, said;

I have been living here for about eight years. At the outset, I was worried about Iranian and Malaysian security and intelligence authorities. But gradually I understood that

20 Although, Malaysia has been a relatively successful multicultural society, there are tensions between the Muslim and Christian communities. For example, the riots by some Muslims in Malaysia and attacks on Christian churches over a recent court rule that allows Christians to call God "Allah" seem baffling and dismaying. Juan Cole, "Allah-Muslim-Christian Controversy in Malaysia," website Informed Comment, www.juancole .com/2010/01/riots-by-some-muslims-in-malaysia-and.html. The laws of Malaysia do not allow leaving Islam, but there are reports showing the number of Muslims who had converted to Christianity in Malaysia. See "Former School Principal Furious Over Apostasy Claim," website MYsinchew.com, www.mysinchew.com/node/62869. On the other hand, some Muslim NGOs are calling for stronger laws against conversions.

It is also reported that some Malaysian ex-Muslims say they are persecuted after converting.

"In countries like Malaysia, Morocco, Jordan and Oman, punishments for apostasy include fines, imprisonment, flogging and exclusion from civil or family rights (such as the right to child custody)."

Political and Legal Status of Apostates in Islam (The Council of Ex-Muslims of Britain, p.58) 
Malaysia is a secure and safe place Some Malaysian Muslims were actually surprised to learn of my conversion. They asked me, 'You come from a Muslim country. So, why did you become a Christian' That gave me a reason to share the message of Jesus Christ. Now my mission is to witness for Christ, invite people to his way and draw their attention to Christianity. I usually baptize new Iranian converts in my home.

In response to the first research question, "The place they have changed their religion" some participants reported to have converted to Christianity in Iran, while others converted after arriving in Malaysia.

On the other hand, among 23 participants who had converted in Iran, 17 said they have emigrated because of the conversion.

The answers to the question about whether their expectations as a new Christian convert have been fulfilled in Malaysia are summarized in the table below.

\begin{tabular}{|c|c|c|c|c|c|}
\hline $\begin{array}{c}\text { Strongly } \\
\text { Disagree }\end{array}$ & Disagree & Neutral & Agree & $\begin{array}{c}\text { Strongly } \\
\text { Agree }\end{array}$ & Total \\
\hline 4 & 7 & 5 & 10 & 18 & 45 \\
$(8.9 \%)$ & $(15.6 \%)$ & $(11.1 \%)$ & $(22.2 \%)$ & $(40.0 \%)$ & 45 \\
\hline
\end{tabular}

Since the 1990s, many Christians have left Iran. ${ }^{21}$ Some of our participants left Iran for reasons, which they claim to be connected to their conversion to Christianity. These included restrictions in openly practicing Christianity in Iran. The services not being presented in Persian language was another reason. ${ }^{22} \mathrm{~A}$ respondent said that the ethnic churches (in Iran) did not accept converts. In addition, she said that churches were merely open to foreigners and diplomats:

... Actually, it was very difficult for converts to go to a church. I wanted to practice freely, but I was not able to practice my new religion and the Sunday Services were limited.

Although there are few people who are legally convicted of apostasy in Iran, some responses referred to social problems and

${ }^{21}$ Report, Iran: Christians and Converts, Landinfo - July 7, 2011 p6

22 According to some reports, Assyrian and Armenian churches nearly do not accept Muslim converts. (Report, Iran: Christians and Converts, Landinfo July 7, $2011 \mathrm{p} 8$ ) 
harassments. A participant, who was a victim of violence, lost her job and moved away from home said,

I faced many problems and lost some of my friends in social networks... They thought I had betrayed my religion.

However, some respondents stated that they had freely travelled to Iran. Four respondents (out of 13) explained that they travelled to Iran with a student visa or dependent visa. One interviewee stated:

I do not announce my conversion. Hence, I do not have problems with the Iranian regime... As an ex-Muslim, I do not see myself as a political opposition.

The problems of converts are social in nature. They include loss of friends and problems arising within social networks, inability to practice one's new religion, churches being closed to Muslims, and offering of services in ethnic languages of indigenous Christians (Armenian and Assyrian) instead of Persian. The alternative of "house churches" is also limited due to state persecution. This includes the firing of the converts from their jobs. Finally there are fear of vigilantes threatening the converts with physical violence.

On the question of the their family and friends' reactions to the subjects referred to rejection by family, being expelled from their homes," shamed for leaving Islam" and "being ostracized."

Three of them had a difficult conversion. One individual described his turning point this way:

... I had to move away from my family and I was banned from my parents' home... Then I moved to Malaysia and started a new life as a refugee.

For Muslim families who piously believe in Islam, a rejection of their religion can be a shock:

I come from strict parents and the conversion was a dishonour to my family, particularly to my father who was ashamed of his son leaving Islam.

Many of the reports did not reveal any harsh reaction from their family to their conversion:

... My brother and I live with my mother who is extremely open- minded although she comes from a strict Muslim family. My brother and I converted to Christianity at the same time. . 
Another convert said;

... Getting away from my family was so difficult. Finally, my parents accepted me as a Christian.

The data below shows the results on the issue of the reasons for converts immigration from Iran. The reasons outlined were:

0 The lack of legal freedom to have free practice in the new religion $(24.4 \%)$

$\circ$ The dearth of economic and social growth and development due to their conversion new religion $(15.6 \%)$

○ Fear of punishment (20.0\%)

o Inappropriate behaviour by Muslims towards apostates (31.1\%)

$\circ$ Alternative reasons $(4.0 \%)$

In response to the question, "Those Muslims who know my conversion to another religion would change their behaviors towards me," the following results were obtained.

\begin{tabular}{|c|c|c|c|c|c|}
\hline $\begin{array}{c}\text { Strongly } \\
\text { Disagree }\end{array}$ & Disagree & Neutral & Agree & $\begin{array}{c}\text { Strongly } \\
\text { Agree }\end{array}$ & Total \\
\hline $\begin{array}{c}11 \\
(24.4 \%)\end{array}$ & $\begin{array}{c}3 \\
(6.7 \%)\end{array}$ & $\begin{array}{c}3 \\
(6.7 \%)\end{array}$ & $\begin{array}{c}8 \\
(17.8 \%)\end{array}$ & $\begin{array}{c}20 \\
(44.4 \%)\end{array}$ & 45 \\
\hline
\end{tabular}

In response to the question, "I am afraid of announcing my conversion to a new religion among Muslims," the results were:

\begin{tabular}{|c|c|c|c|c|c|}
\hline $\begin{array}{c}\text { Strongly } \\
\text { Disagree }\end{array}$ & Disagree & Neutral & Agree & $\begin{array}{c}\text { Strongly } \\
\text { Agree }\end{array}$ & Total \\
\hline $\begin{array}{c}12 \\
(26.7 \%)\end{array}$ & $\begin{array}{c}19 \\
(42.2 \%)\end{array}$ & $\begin{array}{c}5 \\
(11.1 \%)\end{array}$ & $\begin{array}{c}5 \\
(11.1 \%)\end{array}$ & $\begin{array}{c}4 \\
(8.9 \%)\end{array}$ & 45 \\
\hline
\end{tabular}

The question on the familial religiosity was coded as Very strict (religious) parents, Family wasn't too strict, Atheist family, Family pressure in religious matters, Open minded family, Family wasn't too strict, Forced to study the Quran, and Extremely open minded.

A participant who was a young girl expressed;

I, as a youth, disagree with some Islamic rules such as forced hijab, polygamy, banning of music and so on. I often asked myself why shaking hands with the male (or vice versa) is not allowed in Islam.

On contrast, the man born into a religious Muslim family said,

I cannot believe it when some people say that Muslims are leaving Islam because they have a weak faith or they say a 
true Muslim would never change his/her religion. I come from a religious city and my family has a traditional Muslim lifestyle. I prayed and was a Quran reciter.

On the issue of family members' level of religious commitment to the Islamic rules, the results were as follows:

\begin{tabular}{|c|c|c|c|c|c|}
\hline $\begin{array}{c}\text { Too } \\
\text { Little }\end{array}$ & Little & Average & Higher & $\begin{array}{c}\text { Much } \\
\text { Higher }\end{array}$ & Total \\
\hline $\begin{array}{c}21 \\
(46.7 \%)\end{array}$ & $\begin{array}{c}12 \\
(26.7 \%)\end{array}$ & $\begin{array}{c}6 \\
(13.3 \%)\end{array}$ & $\begin{array}{c}5 \\
(11.1 \%)\end{array}$ & $\begin{array}{c}1 \\
(2.2 \%)\end{array}$ & 45 \\
\hline
\end{tabular}

On the issue of whether family was strict on performing the Islamic rituals the results were:

\begin{tabular}{|c|c|c|c|c|c|}
\hline $\begin{array}{c}\text { Strongly } \\
\text { Disagree }\end{array}$ & Disagree & Neutral & Agree & $\begin{array}{c}\text { Strongly } \\
\text { Agree }\end{array}$ & Total \\
\hline $\begin{array}{c}17 \\
(37.8 \%)\end{array}$ & $\begin{array}{c}8 \\
(17.8 \%)\end{array}$ & $\begin{array}{c}13 \\
(28.9 \%)\end{array}$ & $\begin{array}{c}2 \\
(4.4 \%)\end{array}$ & $\begin{array}{c}5 \\
(11.1 \%)\end{array}$ & 45 \\
\hline
\end{tabular}

\section{The Level of Knowledge and Learning About Islam}

On the question of the responses of the level of Islamic knowledge and learning, the coded concepts were Little knowledge of Islam, Weak faith, Having a religious basis, Performing daily prayer and fasting the month of Ramadan, Not knowing how to pray, Not being a real Muslim, Being a faithful person (Mu'min) who believes in everything in the Qur'an, In doubt about the validity of Islam, A true believer, and Having been forced to study the Quran.

Concerning ritual worship acts some years before conversion, a respondent said;

My family has never been religious... I did not know how to pray, how to read the Qur'an in Arabic. Only, we were forced to study the Quran in schools ...

A few respondents stated that they were not practicing their religion. A respondent frankly emphasized the hypocrisy and insincerity of his religious practice as a young man:

...Ramadan was a month in which Muslims must refrain from eating or drinking in public, but my friend and I ate in secret.

About daily prayers, the majority of respondents (9 out of 13) admitted that they did not pray or they did it infrequently. Eight of them said that they did not fast in Ramadan. Also, the majority of them (11 out of 13) were not attending the mosque for several years and that they never attended the Friday prayers (al-Jum'ah). 
Overall, they did not feel that they were adhering to all or most Islamic ritual practices.

Table 4 summarizes the distributions of answers to the following questions.

Q1: When you were a Muslim, what was your level of religious commitment to Islamic rules?

Q2: In terms of religious beliefs and practices, how much did you consider yourself as a real believer in Islamic teachings?

Table 4

\begin{tabular}{|c|c|c|c|c|c|c|}
\hline & $\begin{array}{c}\text { Too } \\
\text { Little }\end{array}$ & Little & $\begin{array}{c}\text { Aver- } \\
\text { age }\end{array}$ & Higher & $\begin{array}{c}\text { Much } \\
\text { Higher }\end{array}$ & Total \\
\hline Q1 & $\begin{array}{c}21 \\
(46.7 \%)\end{array}$ & $\begin{array}{c}12 \\
(26.7 \%)\end{array}$ & $\begin{array}{c}6 \\
(13.3 \%)\end{array}$ & $\begin{array}{c}5 \\
(11.1 \%)\end{array}$ & $\begin{array}{c}1 \\
(2.2 \%)\end{array}$ & 45 \\
\hline Q2 & $\begin{array}{c}9 \\
(20.0 \%)\end{array}$ & $\begin{array}{c}7 \\
(15.6 \%)\end{array}$ & $\begin{array}{c}13 \\
(28.9 \%)\end{array}$ & $\begin{array}{c}7 \\
(15.6 \%)\end{array}$ & $\begin{array}{c}9 \\
(20.0 \%)\end{array}$ & 45 \\
\hline
\end{tabular}

To answer the second part of the research question, "How could someone from Islamic background convert to Christianity and choose to follow Christ as his Savior?" Multiple regressions were conducted.

\section{Conversions Based on Research}

Converts come from different social and professional backgrounds and their previous engagement with Islam are often extremely varied. ${ }^{23}$ On the question of the responses of conversions based on research, there were also some comments expressed by participants. Themes and the coded concepts for the causes of conversion based on research on comparison of religions were Research on Zoroastrianism in Iran, A wide-ranging discussion on Judaism, A brief research on Buddhism in KL, Research on Hindu in KL, Having studied the Bible, and Studying the other types of Islam such as the 'Sufi' orders.

Some participants said that they have compared some religions together. Three participants maintained that;

23 Nadia Marzouki, "Conversion as Statelessness: A Study of Contemporary, Algerian Conversions to Evangelical Christianity," Middle East Law and Governance 4 (2012) 69-105, p90. 
...in Iran a number of other types of Islam is found. I was a follower of Sufism. I used to go to the khanqah for a few months in Tehran. I was quite attracted by the subject of love in Sufism.

... I could not find answers to my questions in Islam. I do not claim that I am an expert in religions, but I studied Zoroastrianism and Judaism too.

...I began to understand why Christian countries are developed and rich. From that point on, I began to do my own research. I was not satisfied with reading the books written by Muslim scholars... I found peace, truth, kindness and love in Christianity.

It is the parents who make children a Muslim, Zoroastrian, Jew or Christian. I had a brief research on Buddhism and Hindu in KL.

While in some answers it appeared that there were personal reasons that played some role in the individual's turning point in their conversion, such a case was expressed by a participant called Convert 10. She expressed emotional factors as a turning point for conversion. The following describes her tendency:

I lived in the United States for five years. Although I converted to Christianity there, my tendency toward Christianity began in youth when I lived in Tehran and had a good relationship with Iranian-Armenians. ${ }^{24}$

Convert 13 describes his familiarity with Christianity as an impulsive entrance to a church:

I first became interested in Christianity when I accidentally went to church in Kuala Lumpur. [In the binging] I was attracted to the singing and the music of the church.

The experience of Convet10 reminds us that conversion is a multifaceted process. This finding is in agreement with Duane Alexander Miller's (2012) findings that narrated the conversion experience of a woman from Shi'a Islam to Christianity. ${ }^{25}$

${ }^{24}$ See another conversion experience by an Iranian woman, Duane Alexander Miller, "The Conversion Narrative of Samira: From Shi'a Islam to Mary, her Church, and her Son", St Francis Magazine 5/5, October 2009, pp 81-92.

25 Duane Alexander Miller, "The Secret World of God: Aesthetics, Relationships, and the Conversion of 'Frances' from Shi'a Islam to Christianity," Published in Diaspora Studies, retrieved on April 2012, www .GlobalMissiology.org 
In response to the question, "How many religions did you compare before choosing their new religion?" 33 (73.3\%) said they just compared one religion while $7(15.6 \%)$ had compared two religions and only $5(11.1 \%)$ had compared more than two religions.

When asked about which religions (Hindu, Zoroastrian, Jew, Buddhist, other) did they study, their responses were:

\begin{tabular}{|c|c|c|c|c|c|}
\hline Hinduism & Zoroastrian & Judaism & Buddhism & Nothing & Total \\
\hline 3 & 11 & 4 & 3 & 24 & 45 \\
$(6.7 \%)$ & $(24.4 \%)$ & $(8.9 \%)$ & $(6.7 \%)$ & $(53.3 \%)$ & 4 \\
\hline
\end{tabular}

This was while $6(13.3 \%)$ were you familiar (academically or non-academically) with other types of Islam and 39 (86.7) were not.

Table 5 summarizes the distributions of answers to the following questions.

Q3: Was your knowledge and learning about Islam was enough to leave it?

Q4: Did you know how to recite the Quran?

Q5: Were you familiar with the translation of the Qur'an?

Table 5

\begin{tabular}{|c|c|c|c|c|c|c|}
\hline & $\begin{array}{c}\text { Strongly } \\
\text { Disagree }\end{array}$ & Disagree & Neutral & Agree & $\begin{array}{c}\text { Strongly } \\
\text { Agree }\end{array}$ & Total \\
\hline Q3 & $\begin{array}{c}18 \\
(40.0 \%)\end{array}$ & $\begin{array}{c}11 \\
(24.4 \%)\end{array}$ & $\begin{array}{c}5 \\
(11.1 \%)\end{array}$ & $\begin{array}{c}5 \\
(11.1 \%)\end{array}$ & $\begin{array}{c}6 \\
(13.3 \%)\end{array}$ & 45 \\
\hline Q4 & $\begin{array}{c}18 \\
(40.0 \%)\end{array}$ & $\begin{array}{c}16 \\
(35.6 \%)\end{array}$ & $\begin{array}{c}6 \\
(13.3 \%)\end{array}$ & $\begin{array}{c}2 \\
(4.4 \%)\end{array}$ & $\begin{array}{c}3 \\
(6.7 \%)\end{array}$ & 45 \\
\hline Q5 & $\begin{array}{c}14 \\
(31.1 \%)\end{array}$ & $\begin{array}{c}14 \\
(31.1 \%)\end{array}$ & $\begin{array}{c}10 \\
(22.2 \%)\end{array}$ & 0 & $\begin{array}{c}7 \\
(15.6 \%)\end{array}$ & 45 \\
\hline
\end{tabular}

\section{Religious Reasons}

Some participants were attributed the desire to conversion to "doubt about the Quran" and others to "doubt about Islam." Themes and the coded concepts emerged in the context of doubt about Islam were Islam being associated with extremism, Stoning being allowed in Islam, Compulsion of prayer based on a blind faith, Lack of spiritual comfort and relief in Islam, Islam encouraging Muslims to judge another, Religious capital in Islam, Domestic violence, Women's rights, Divorce rights of women, 
Being forced to wear hijab, Family pressure to wear religious dress, Being confused about God, Doubt about the Quran was broken down to the following assumptions, It is written by humans, It is created by the mind of Mohammad, Didn't know the recitation of Quran, and Didn't understand the meaning of the Qur'an.

In expressing unhappiness with performing practical rituals and rules of Islam, some respondents decried the imposition of Islamic Law. One respondent said,

For years, Islamic position with regards to the punishments and religious capital in Islam was my question. I could not understand why the Shari'ah allowed death by stoning or to cut off the thief's hand, and lashing in public... Then one day I read some Christian literature and I found the teachings of Christianity made much more sense... in fact Christianity is a personal relationship with God.

One more convert emphasized on the difference between Islam and Christianity as the difference between a religion of constraining law and one of love:

... There is so much violence and oppression in the Quran itself. Everyone wants an easy religion... I was surprised to find that Christianity is very simple and pure that makes it very convenient. Islam is based on a strict shari'a law, but Christianity is based on love and life.

Another converts said;

Muslims' claim that Muhammad was a messenger of God is not really logical. Why did Muhammad and his followers kill non-Muslims? Why apostasy is punishable by the death?

A participant claimed that no one would answer the questions about the doubts with the Qur'an. He spoke of the lack of spirituality in Islam:

... I was always scared of death and afraid of God. For a long time, my doubts and confusions regarding God, Islam, and the prophet remained in dormant... I started to ask my friends, university professors, and clergymen some questions. But I was not convinced by the answers...

Another participant mentioned the fear of God in Islam: I have been struggling with my daily prayers since I was young. Step by step, I got away from it and also from fasting in Ramadan... I always feared hell, when I was growing up. I 
was constantly afraid of God. I do not want a Holy Book that only talks about punishment and war. ${ }^{26}$

Another participant pointed to Qur'anic concepts and the violence mentioned in the Qur'an and they did not believe that it was a divine speech:

Qur'an is not the word of God. It is a figment of the mind of Muhammad or it was copied from Christianity and Judaism. Muslims constantly claim that Islam is the most peaceful religion in the world. Unfortunately, there are very few verses of tolerance and peace, but there are verses of violence.

Table 6 summarizes the distributions of answers to the following questions.

Q6: Did you believe in the Qur'an as a divine speech?

Q7: Did the spirituality in Islam give you comfort to make you satisfied?

Q8: Was ambiguity in doctrinal and theoretical issues effective on your changing religion?

Q9: Did performing practical rituals and decrees of Islam affect your conversion?

Q10: Does the new religion provide the space for you?

Q11: When you discussed your questions, did the given answers convince you?

Table 6

\begin{tabular}{|c|c|c|c|c|c|c|}
\hline & $\begin{array}{c}\text { Strongly } \\
\text { Disagree }\end{array}$ & Disagree & Neutral & Agree & $\begin{array}{c}\text { Strongly } \\
\text { Agree }\end{array}$ & Total \\
\hline Q6 & $\begin{array}{c}11 \\
(24.4 \%)\end{array}$ & $\begin{array}{c}14 \\
(31.1 \%)\end{array}$ & $\begin{array}{c}6 \\
(13.3 \%)\end{array}$ & $\begin{array}{c}2 \\
(4.4 \%)\end{array}$ & $\begin{array}{c}12 \\
(26.7 \%)\end{array}$ & 45 \\
\hline Q7 & $\begin{array}{c}8 \\
(17.8 \%)\end{array}$ & $\begin{array}{c}3 \\
(6.7 \%)\end{array}$ & $\begin{array}{c}6 \\
(13.3 \%)\end{array}$ & $\begin{array}{c}6 \\
(13.3 \%)\end{array}$ & $\begin{array}{c}20 \\
(48.9 \%)\end{array}$ & 45 \\
\hline Q8 & $\begin{array}{c}13 \\
(28.9 \%)\end{array}$ & $\begin{array}{c}16 \\
(35.6 \%)\end{array}$ & $\begin{array}{c}10 \\
(22.2 \%)\end{array}$ & $\begin{array}{c}3 \\
(6.7 \%)\end{array}$ & $\begin{array}{c}3 \\
(6.7 \%)\end{array}$ & 45 \\
\hline
\end{tabular}

26 These findings of the current study are consistent with a survey of 100 former Muslims by Georges Houssney, The vast majority of respondents who were mostly moderate Muslims (40\%) or nominal Muslims (40\%) before their conversions (20\% were self-described "fanatics")-said they viewed their relationship with Allah as based on fear or duty. See: Factors leading to conversion of Muslims to Christ. http://biblicalmissiology.org 


\begin{tabular}{|c|c|c|c|c|c|c|}
\hline & $\begin{array}{c}\text { Strongly } \\
\text { Disagree }\end{array}$ & Disagree & Neutral & Agree & $\begin{array}{c}\text { Strongly } \\
\text { Agree }\end{array}$ & Total \\
\hline Q9 & $\begin{array}{c}5 \\
(11.1 \%)\end{array}$ & $\begin{array}{c}4 \\
(8.9 \%)\end{array}$ & $\begin{array}{c}12 \\
(26.7 \%)\end{array}$ & $\begin{array}{c}13 \\
(28.9 \%)\end{array}$ & $\begin{array}{c}11 \\
(24.4 \%)\end{array}$ & 45 \\
\hline Q10 & $\begin{array}{c}16 \\
(35.6 \%)\end{array}$ & $\begin{array}{c}8 \\
(17.8 \%)\end{array}$ & $\begin{array}{c}5 \\
(11.1 \%)\end{array}$ & $\begin{array}{c}6 \\
(13.3 \%)\end{array}$ & $\begin{array}{c}10 \\
(22.2 \%)\end{array}$ & 45 \\
\hline Q11 & $\begin{array}{c}18 \\
(40.0 \%)\end{array}$ & $\begin{array}{c}11 \\
(24.4 \%)\end{array}$ & $\begin{array}{c}3 \\
(6.7 \%)\end{array}$ & $\begin{array}{c}6 \\
(13.3 \%)\end{array}$ & $\begin{array}{c}7 \\
(15.6 \%)\end{array}$ & 45 \\
\hline
\end{tabular}

In response to the question, "Who would help you when you got questions, faced problems and wanted to criticize Islam?" the results were:

\begin{tabular}{|c|c|c|c|c|c|c|}
\hline $\begin{array}{c}\text { University } \\
\text { Professors }\end{array}$ & $\begin{array}{c}\text { Muslim } \\
\text { Clergy }\end{array}$ & Family & Friends & Nobody & Other & Total \\
\hline $\begin{array}{c}1 \\
(2.2 \%)\end{array}$ & $\begin{array}{c}2 \\
(4.4 \%)\end{array}$ & $\begin{array}{c}7 \\
(15.6 \%)\end{array}$ & $\begin{array}{c}6 \\
(13.3 \%)\end{array}$ & $\begin{array}{c}6 \\
(13.3 \%)\end{array}$ & $\begin{array}{c}23 \\
(51.1 \%)\end{array}$ & 45 \\
\hline
\end{tabular}

The lifestyle of Christians might have been one of the attractions for the converts. Themes and the coded concepts emerged in the context were Happiness, Peace, Be good to others, Easy religion, Bible being clearer and making sense, Giving service to others, Kindness and love, Truthfulness, Honesty, Christianity is more fun, Christianity teaches people to love and forgive another, More tolerant than Islam, Most loving, No gap between Christians beliefs and their practice and Compassion.

Some participants said they were attracted to Christian faith because of the lifestyle of the Christians:

I don't like the behaviour of some Muslims because they're such hypocrites. You cannot see a gap between the beliefs and practices of most of the members of our Church.

I felt that Church friends offer joy, service, kindness, and compassion to the others. Actually, my heart was attracted to this religion by Christ's love for all people.

The findings of the current study are consistent with a field research performed between 1991 and 2007, which was a survey of 750 Muslims who had decided to follow Christ. They filled out an extensive questionnaire on that basic question. The respondents were from 30 countries and 50 ethnic groups and they represented every major denomination in the Muslim world. This survey 
showed that "The lifestyle of Christians" was one of the five predominant reasons they chose to follow Christ.

\section{Benefits and Tendency toward Christianity}

On the question about the benefits and tendency toward Christianity in a few narratives, it appeared that Christian propaganda and missionary efforts played some role in the individual's turning point in the process of conversion. A participant claimed that he had been advised to approach a Christian missionary by his friend:

My challenge with my religion started in Tehran. Previously, I met a house church leader. I had never met a Christian in my life... She was always very encouraging to parties hosted by other conversions.

One participant who considered himself as a religious Christian who helps other Muslims to find the path of salvation said,

I'm not afraid of anything; however, some of my friends hide their conversion. I also know other ex-Muslims who are not afraid to speak up against intolerant religions... I am just doing my duty as a pastor.

Three of the subjects claimed that their conversion was because of missionary contact. The next most important influence was the media. A participant said he was attracted to the Christian faith because of a film:

The film [Passion of the Christ] changed my life. I'm sure, that was just the grace of our lord Jesus Christ. I made a decision to read the Bible.

The third biggest influence listed by respondents was getting social or financial supports. A number of studies have found that there are opportunities for Iranian converts or minorities that are also asylum seekers. ${ }^{27}$. Also, a conversion can be used as a

27 "The UNHCR office in Eastern Turkey reported that they received applications for asylum from Iranian converts (meeting in Van, March 2011). UNHCR estimated that approximately 20-25 percent of the asylum seekers reported that they are converts. Some of them have converted in Iran; others are baptized in Van during the processing of their application for asylum. A common feature of Iranian converts in Ankara and Van is that they almost without exception are ethnic Persians and were previously Shia Muslims." Report Iran: Christians and Converts, Landinfo - July 7, 2011, 6. 
strategy for emigration. According to a research article by Sebnem Koser Akcapar (2006, p. 819), based on her fieldwork among Iranian asylum seekers carried out in Turkey, she argues that conversion from Islam to Christianity is used as a migration strategy. She demonstrates how Iranian asylum seekers use religion and newly acquired social and religious networks within different churches and congregations in Turkey to reach the West in a shorter period of time as refugees. ${ }^{28}$

There are some participants reporting that not all who say they have converted are "real." In other words, some individuals convert out of a desire for salvation while others seek conversion as a tool to get other benefits ${ }^{29}$. In some Muslim countries, the hope of receiving a visa to a Western country can be the main motivation for Muslim conversions: ${ }^{30}$

I didn't receive any support. Unfortunately I know some people - my customers, our church members- who change faith to get social or financial support especially obtaining visa and achieving an asylum status. ${ }^{31}$

One of the most interesting findings of this survey was the question that if the financial benefits offered would help to change the religion.

\begin{tabular}{|c|c|c|c|c|c|}
\hline $\begin{array}{c}\text { Strongly } \\
\text { Disagree }\end{array}$ & Disagree & Neutral & Agree & $\begin{array}{c}\text { Strongly } \\
\text { Agree }\end{array}$ & Total \\
\hline $\begin{array}{c}8 \\
(17.8 \%)\end{array}$ & $\begin{array}{c}3 \\
(6.7 \%)\end{array}$ & $\begin{array}{c}6 \\
(13.3 \%)\end{array}$ & $\begin{array}{c}3 \\
(6.7 \%)\end{array}$ & $\begin{array}{c}25 \\
(55.6 \%)\end{array}$ & 45 \\
\hline
\end{tabular}

These findings were supported by the study conducted by Sebnem Koser Akcapar in 2006: "Certainly, in Turkey there were some opportunistic people who believed that conversion could be their only way to reach the West."

28 About Iranian converts in Turkey see also: Report on the Situation of Iranian Refugees in Turkey, Omid Advocates for Human Rights, Report on the Situation of Iranian Refugees in Turkey, retrieved on June 2010, http://www .omidadvocates.org/Resources--reports.html (accessed September 4, 2012).

29 Malcolm L. Rigsby (2012) noted that prisoners often use religion as a tool to gain privileges that may create status among the general prison population.

30 Nadia Marzouki, "Conversion as Statelessness: A Study of Contemporary Algerian Conversions to Evangelical Christianity," Middle East Law and Governance 4 (2012), 69-105.

31 [I have been seeing some of the converts who receive confirmation letter and acceptance from pastor church.] 
Table 7 summarizes the distributions of answers to the following questions.

Q12: Is it possible that getting a residence permit from other countries would help to change religion?

Q13: Did Christian missionaries' encouragement have an influence on your conversion?

Q14: Do you propagate your new religion?

Table 7

\begin{tabular}{|l|c|c|c|c|c|c|}
\hline & $\begin{array}{c}\text { Strongly } \\
\text { Disagree }\end{array}$ & Disagree & Neutral & Agree & $\begin{array}{c}\text { Strongly } \\
\text { Agree }\end{array}$ & Total \\
\hline Q12 & $\begin{array}{c}6 \\
(13.3 \%)\end{array}$ & $\begin{array}{c}5 \\
(11.1 \%)\end{array}$ & $\begin{array}{c}8 \\
(17.8 \%)\end{array}$ & $\begin{array}{c}11 \\
(24.4 \%)\end{array}$ & $\begin{array}{c}15 \\
(33.3 \%)\end{array}$ & 45 \\
\hline Q13 & $\begin{array}{c}14 \\
(31.1 \%)\end{array}$ & $\begin{array}{c}9 \\
(20.0 \%)\end{array}$ & $\begin{array}{c}5 \\
(11.1 \%)\end{array}$ & $\begin{array}{c}9 \\
(20.0 \%)\end{array}$ & $\begin{array}{c}8 \\
(17.8 \%)\end{array}$ & 45 \\
\hline Q14 & $\begin{array}{c}12 \\
(26.7 \%)\end{array}$ & $\begin{array}{c}19 \\
(42.2 \%)\end{array}$ & $\begin{array}{c}5 \\
(11.1 \%)\end{array}$ & $\begin{array}{c}5 \\
(11.1 \%)\end{array}$ & $\begin{array}{c}4 \\
(8.9 \%)\end{array}$ & 45 \\
\hline
\end{tabular}

Regarding how they heard about the new religion, the results for 45 subjects are summarised as follows. Participating in religious sessions, 8 (17.8\%); study, 14 (31.1\%); media, 2 (4.4\%); religious missionaries, $1(2.2 \%)$; connection with Iranian Armenians, 1 (2.2\%); friends, 2 (4.4\%); two ways, 11 (24.4\%); and three ways, $6(13.3 \%)$.

Conversion efforts are also promoted by media such as books. Some Internet sites created by Christian scholars and organizations reserve a significant space for literature on Muslims converting to Christians. Some missionary activities by media are focused on Persian speakers. For example, on the Iranian Christian International (ICI) website, we read: "Providing counseling, communication, information and referral services and monitoring human rights of Christians in Muslim countries and providing advocacy on their behalf." ${ }^{32}$ According to reports, there are missionary activities with regard to Iranian Muslims through social works among Persian-speaking asylum seekers and refugees. Also, according to the Danish Refugee Council \&

32 "Iranian Christians International, Inc", website Kelisa Online, www .iranchristians.org/ministries.shtml 
Danish Immigration Service (2009, p. 33-34) it is possible to convert "online" from Iran. Iranians could contact US-based TV stations and receive religious instructions, a certificate of baptism and a recommendation from American churches. Although established for the purpose of undertaking missionary activity among Persian-speaking Iranian refugees in other countries such as Turkey (Sebnem Koser Akcapar 2006, p. 820.) There is no a well-known Christian missionary organization in Malaysia.

The distribution of the answers to the question "What are the strong points of the new religion you accepted in comparison with Islam?" was as follows. Patience, 1 (2.2\%); kindness, tolerance, 14 (31.1\%); faithfulness of Christian followers, 1 (2.2\%); two points, 5 (11.1\%); three points 13 (28.9\%); four points, 8 (17.8\%).

\section{Socio-political Reasons}

By examining interviews conducted with those who have experienced a religious conversion, we attained a better understanding of the extent to which conversion is a religious or a political phenomenon. In this study, some participants mentioned the religious rule in the Islamic government as a reason for why they were attracted to Christianity. In these cases, it seems that conversion to Christianity does appear to affect the political outlook of the converts:

Islamic concepts didn't make me relaxed and peaceful from inside. In my opinion, lots of the Islamic doctrine is political, not spiritual, especially in the Middle East countries... Muslim leaders see the religion as a tool, not a goal.

The theme was also developed by another respondent:

I would like to say honestly that the hate of the Iranian government and violence against opponents, and women was the main reason [...] I'm looking for a chance for something better.

Table 8 summarizes the distributions of answers to the following questions.

Q15: Did politics influence your conversion?

Q16: Did the political situation in Iran affect your conversion?

Q17: Nowadays, do you believe that leaving Islam was a religious issue? 
Q18: Nowadays, do you believe that leaving Islam was a political issue?

Q19: Does the conversion of some Muslims bring about intellectual and social instability in an Islamic society?

Q20: Did the attitude of Islamic leaderships affect your religious conversion?

Q21: Did theocracy affect your changing religion?

Q22: Do those Muslims who convert to a new religion intend to undermine Islam?

Q23: Does the horror of retribution in Islamic law prevent conversion by Muslims?

Table 8

\begin{tabular}{|l|c|c|c|c|c|c|}
\hline & $\begin{array}{c}\text { Strongly } \\
\text { Disagree }\end{array}$ & Disagree & Neutral & Agree & $\begin{array}{c}\text { Strongly } \\
\text { Agree }\end{array}$ & Total \\
\hline Q15 & $\begin{array}{c}18 \\
(40 \%)\end{array}$ & $\begin{array}{c}11 \\
(24.4 \%)\end{array}$ & $\begin{array}{c}3 \\
(6.7 \%)\end{array}$ & $\begin{array}{c}6 \\
(13.3 \%)\end{array}$ & $\begin{array}{c}7 \\
(15.6 \%)\end{array}$ & 45 \\
\hline Q16 & $\begin{array}{c}8 \\
(17.8 \%)\end{array}$ & $\begin{array}{c}11 \\
(24.4 \%)\end{array}$ & $\begin{array}{c}20 \\
(44.4 \%)\end{array}$ & $\begin{array}{c}2 \\
(4.4 \%)\end{array}$ & $\begin{array}{c}4 \\
(8.9 \%)\end{array}$ & 45 \\
\hline Q17 & $\begin{array}{c}4 \\
(8.9 \%)\end{array}$ & $\begin{array}{c}4 \\
(8.9 \%)\end{array}$ & $\begin{array}{c}22 \\
(42.2 \%)\end{array}$ & $\begin{array}{c}10 \\
(22.2 \%)\end{array}$ & $\begin{array}{c}5 \\
(11.1 \%)\end{array}$ & 45 \\
\hline Q18 & $\begin{array}{c}2 \\
(4.4 \%)\end{array}$ & $\begin{array}{c}7 \\
(15.6 \%)\end{array}$ & $\begin{array}{c}9 \\
(20.0 \%)\end{array}$ & $\begin{array}{c}10 \\
(22.2 \%)\end{array}$ & $\begin{array}{c}17 \\
(37.8 \%)\end{array}$ & 45 \\
\hline Q19 & $\begin{array}{c}10 \\
(22.2 \%)\end{array}$ & $\begin{array}{c}6 \\
(13.3 \%)\end{array}$ & $\begin{array}{c}8 \\
(17.8 \%)\end{array}$ & $\begin{array}{c}6 \\
(13.3 \%)\end{array}$ & $\begin{array}{c}15 \\
(33.3 \%)\end{array}$ & 45 \\
\hline Q21 & $\begin{array}{c}5 \\
(11.1 \%)\end{array}$ & $\begin{array}{c}14 \\
(8.9 \%)\end{array}$ & $\begin{array}{c}17 \\
(26.7 \%)\end{array}$ & $\begin{array}{c}13 \\
(28.9 \%)\end{array}$ & $\begin{array}{c}11 \\
(24.4 \%)\end{array}$ & 45 \\
\hline Q22 & $\begin{array}{c}11 \\
(24.4 \%)\end{array}$ & $\begin{array}{c}5 \\
(6.7 \%)\end{array}$ & $\begin{array}{c}3 \\
(11.1 \%)\end{array}$ & $\begin{array}{c}6 \\
(6.7 \%)\end{array}$ & $(13.3 \%)$ & 45 \\
\hline Q23 & $\begin{array}{c}14 \\
(31.1 \%)\end{array}$ & $\begin{array}{c}15 \\
(33.3 \%)\end{array}$ & $\begin{array}{c}4 \\
(8.9 \%)\end{array}$ & $\begin{array}{c}20 \\
(22.2 \%)\end{array}$ & 45 \\
$(44.4 \%)$
\end{tabular}

In response to the question, "Did you know the punishments and decrees of Islam especially for those who change their religion?" 35 (77.8\%) knew completely, 5 (11.1\%) knew so little, and $5(11.1 \%)$ did not knew. 
In response to the question, "What is your current viewpoint about Islam?" the results were:

\begin{tabular}{|c|c|c|c|c|}
\hline Abhorrence & Kind & $\begin{array}{c}\text { Does not } \\
\text { Matter }\end{array}$ & $\begin{array}{c}\text { Didn't know } \\
\text { about Islam }\end{array}$ & Total \\
\hline $\begin{array}{c}8 \\
(17.8 \%)\end{array}$ & $\begin{array}{c}6 \\
(13.3 \%)\end{array}$ & $\begin{array}{c}9 \\
(20.0 \%)\end{array}$ & $\begin{array}{c}22 \\
(48.9 \%)\end{array}$ & 45 \\
\hline
\end{tabular}

\section{Results}

The results of this field research can be summarized in four categories:

\section{Role of Research in Conversion}

According to the studies made in terms of religious reasons, they did not come from a religious family; therefore, they did not have a rich religious background. Even some of them stated that they have been Muslim just by name, and their knowledge of Islam was quite limited or they did not have any knowledge of Islam at all. In response to the question when they were a Muslim, and what was their level of religious commitment to Islamic rules, the results were $46.7 \%$ too little, $26.7 \%$ little, while $11.1 \%$ high, $2.2 \%$ much higher. This was while the highest percentage of the results (75\%) showed that they were not able to read the Quran, and 62\% of the respondents were not familiar with the translation of the Quran.

Another result that could be concluded based on the interviews was that the subjects' religion conversions had not been based on any research. They had not done so much research about different religions to help them with choosing the premier religion. Distribution of the answers to the question how many religions had they compared before choosing their new religion was interesting: $73.3 \%$ said one religion; a great fraction of them (68\%) stated that their knowledge and learning about Islam was not enough to leave it. Concerning a question about the familiarity (academically, non-academically) of the respondents with other types of Islam (e.g. Sufism), 39 people (86.7\%) of those who were interviewed indicated that they had neither faced nor studied one and 6 people (13.3\%) said "Yes".

In addition, this group not only did not know much about Islam but also they did not go on a research to find answers to the doubts and questions they had about Islam. 


\section{Social and Political Reasons}

Although some interviewees have feared for their own safety or the safety of their households and they have claimed that the lives of converts are particularly at risk because Islamic-religious authorities view apostasy as a criminal offence. However, we should not necessarily look at this issue from a political angel. Although, political conditions in Iran have an influence on this issue, it is not limited to just politics. In response to the question if politics influenced changing their religion, the result was $64.0 \%$ disagreed. In addition, in response to the question if the political situation in Iran affected their conversion to another religion, only $13 \%$ agreed and approximately $30 \%$ disagreed. Research findings showed that social reasons and ethics in Iran as an Islamic country were more effective than political conditions. Those who converted clearly stated that in an Islamic society everybody from the family members of a person to the whole society are opposed to religious conversion, and they were rejected by their own families. It can be found in the reports of some people, often within a Muslim family, the family members are radically opposed to conversion to Christianity. Some of the subjects said that they hid their conversion fearing to be excluded from their families and being estranged from their spouse and children. One of the subjects claimed, "if my family finds out I am no longer a Muslim they will completely cut me off." On this subject, another subject stated that her family still did not accept her conversion and she is still arguing with her family about it.

Therefore, one-third of the people declared that how Muslims in Iran behave towards them was the reason of thier migrations. Whereas $11(24.4 \%)$ claimed that it was the result of the lack of legal freedom to have free practice in the new religion, $9(20.0 \%)$ stated that the fear of punishment was the reason for their flight. This issue has been confirmed in another way because when the subjects were asked about the reactions of other Muslims toward their conversions, (44/4\%) strongly agreed that Muslims' behaviour toward them changed. 


\section{Christian Missionaries and Invitation to Religious- Conversion}

Christian propaganda and missionary efforts played some role in the individual's turning point in the process of conversion. A few participants claimed that they had been advised by missionaries to approach Christianity.

After the Islamic Revolution in Iran (1979), it is officially illegal to proselytize; therefore, the Christian missionaries had a little impact on the conversion. In response to the question if Christian missionaries' encouragements had an influence on their conversion, about $70 \%$ of the participants disagreed. However, the new ways of proselytizing have had some influences on them. Therefore, some participants said that they were attracted to the Christian faith because of films, house church leaders, books about Christianity and the life of Christ, as well as Persian Christian Satellite TV and Radio networks broadcast for Farsi speaking people.

\section{Personal Reasons: the Effect of Personal Benefits on Conversion}

It is observed that groups of Iranian people are living in Malaysia as a refugee just in pursue of a hope to become a resident in a western country. As far as it is a good reason for one to claim that they were persecuted in order to grant their asylum, some of these people can be judged to have converted to seize such an opportunity. Among the respondents of the present study were some who insisted that there was a relationship between their conversion and getting a residence permit from a western country. The respondents would also believe that the possibility of getting a residence permit from other countries would help to change religion. In response to the question, "Does the possibility of getting a residence permit from other countries help to change religion?" Overall, 57\% agreed on this matter; an interesting point of this research was that $70 \%$ of the participants believed that financial proposals had an impact on their conversion. Results of the study have shown that some people have converted their religion for reasons other than religious and political ones such as personal reasons, personal feelings, romantic events, or family 
relations: sometimes they convert their religion under the influence of Christianity.

\section{Conclusion}

The study shows that there are a couple of differences between the apostasy during the early period of Islam and contemporary era; however, there are a few similarities.

Financial issues were the main reason by which people left the religion of Islam. Political issues also affected religious people to divert from Islam to another religion.

The minister's propagation had an influence on converting from one religion to another in both early and contemporary era.

The study of Islamic sources including narrative-based sources as well as AHadith has helped the researcher to aptly analyze the current situation of a Muslim community.

Apparently, it is only the way that Muslims are impressed by Christianity, and their conversion have changed while the contents and themes have not changed a lot. In the past, people had a faceto-face relationship due to the traditional structure of the society, and therefore other religions turned to be attractive through discourse with other people. However, in the present century, mass communication media have changed the mode our relationships and therefore the religious missionary propaganda. Albeit, the passion, hope for a better life, and being impressed by the lifestyles of non-Islamic societies are still intact and remained the same.

\section{References}

"6 Million Muslims LEAVE Islam Every Year," website Virtue Online, www.virtueonline.org/portal/modules/news/print.php ?storyid $=3995$

"Former School Principal Furious Over Apostasy Claim," website MYsinchew.com, www.mysinchew.com/node/62869.

"Iranian Christians International, Inc", website Kelisa Online, www.iranchristians.org/ministries.shtml

Al-Jabri, Mohammed Abed. Democracy, Human Rights and Law in Islamic Thought. N.p.: I. B. Tauris \& Co Ltd, 2009.

Asmussen, Jes Peter. "Christians in Iran," The Cambridge History of Iran 3, no.2 (1983), 924-948. 
Colson, Chuck. "They Want Jesus Instead:" Why Muslims Convert, the Ginger Jar, website https://gingerjar2.wordpress .com/2008/03/25/they-want-jesus-instead-why-muslimsconvert/

Donner, Fred M. The Early Islamic Conquests. N.p.: Princeton University Press, 1981.

El-Awa, Mohamed S. Punishment in Islamic Law. IL: American Trust Publication, 1981.

Juan Cole, "Allah-Muslim-Christian Controversy in Malaysia," website Informed Comment, www.juancole.com/2010/01 /riotsby-some-muslims-in-malaysia-and.html.

Marzouki, Nadia. "Conversion as Statelessness: A Study of Contemporary Algerian Conversions to Evangelical Christianity," Middle East Law and Governance 4 (2012), 69105.

Marzouki, Nadia. "Conversion as Statelessness: A Study of Contemporary, Algerian Conversions to Evangelical Christianity," Middle East Law and Governance 4 (2012) 69105, p90.

Marzouki, Nadia. "Conversion as Statelessness: A Study of Contemporary Algerian Conversions to Evangelical Christianity," Middle East Law and Governance 4 (2012), 69105.

Miller, Duane Alexander. "Iranian Diaspora Christian in the American Midwest \& Scotland: Historical Background, Present Realities, \& Future Challenges" in Global Missiology 9, no. 2 (January 2012).

Miller, Duane Alexander. "The Conversion Narrative of Samira: From Shi'a Islam to Mary, her Church, and her Son," St Francis Magazine 5/5 (October 2009), pp 81-92.

Miller, Duane Alexander. "The Secret World of God: Aesthetics, Relationships, and the Conversion of 'Frances' from Shi'a Islam to Christianity," Published in Diaspora Studies, retrieved on April 2012, www.GlobalMissiology.org

Pink, Johanna. “A Post-Qur'ānic Religion Between Apostasy and Public Order: Egyptian Muftis and Courts on the Legal Status of the Bahā'̄i Faith," Islamic Law and Society 10, no.3 (2003), 409-434.

Report Iran: Christians and Converts, Landinfo - July 7, 2011 p6. 
Report on the Situation of Iranian Refugees in Turkey, Omid Advocates for Human Rights, Report on the Situation of Iranian Refugees in Turkey, retrieved on June 2010, http://www.omid advocates.org/

Rigsby, Malcolm L. "Religious Conversion in Prison and Its Directions: Community Identity, Religious Dogma, and Exclusivist or Inclusivist Religiosity in American Prisons." PhD Thesis, Texas Woman's University, 2012.

Shaikh Abdu Rahman. Punishment of Apostasy in Islam. Selangor: The Other Press, 2006. 
Gholamreza and Faisal, Iranian Christian Converts in Malaysia 